GLOSSARY

\title{
International cooperation and health. Part I: issues and concepts
}

\author{
Martin McKee, Anna B Gilmore, Nina Schwalbe
}

J Epidemiol Community Health 2005;59:628-631. doi: 10.1136/jech.2003.013532

The world is increasingly shaped by powerful global forces, many of which have consequences for human health and the social, economic, and environmental factors that influence health are increasingly determined at a supranational level. As a result, local or national level efforts to influence health determinants can have only a limited impact and it is all too easy for the individual public health practitioner to feel powerless. Yet while public health practitioners, on their own, may indeed be comparatively powerless, together they can achieve a great deal. Part I of this glossary explores a range of issues that arise as they seek to make a difference.

See end of article for authors' affiliations

Correspondence to: Professor M McKee, European Centre on Health of Societies in Transition, London School of Hygiene and Tropical Medicine, Keppel Street, London WCIE 7HT, UK; martin.mckee@lshtm.ac.uk

Accepted for publication 4 August 2004
$\mathrm{T}$ he tasks facing the global health community as it responds to powerful global forces that threaten health are twofold. Borrowing a medical metaphor, the first task is to make a diagnosis. Making a diagnosis often entails making what is otherwise invisible visible. The connection between global forces and individual tragedies, such as a premature death, is often far from clear. Yet the linkages can be found, providing one takes a sufficiently broad perspective. ${ }^{1}$ Africa, tragically, provides all too many examples. Children in Sierra Leone, struggling to come to terms with having had their arms hacked off in the civil war are victims of the global trade in diamonds. ${ }^{2}$ Entire communities massacred in the civil war that has waged in the Democratic Republic of the Congo have died primarily because they had the misfortune to live above the world's major source of tantalum, the metal used to make chips in mobile phones. ${ }^{3}$ As Collier has noted, in a detailed study of the determinants of human wellbeing, living in a country that is rich in primary resources is, paradoxically, a major disadvantage. ${ }^{4}$ Research on the health effects of climate change offer many more examples, showing how events in one place can lead to death and disease many thousands of miles away, contributing to events as diverse as floods, forest fires, landslides, and changing distribution of communicable disease vectors. ${ }^{5}$ Demonstrating these links demands new skills, drawing on a wide range of disciplines, many of which lie outside the traditional public health portfolio. ${ }^{6}$ Thus, international cooperation to diagnose the problems the world faces should cross not only national frontiers but also disciplinary ones. It needs to draw not only on an understanding of epidemiology but also on such diverse issues such as international law, patterns of trade, meteorology, and basic science. The scale of global phenomena means that prospective experimentation will be rare; instead the investigator will require imagination to identify natural experiments that can produce the necessary insights. As the issues often involve powerful interests that strive to conceal the evidence, or worse, to distort it, ${ }^{7}$ the investigator will also require the skills more often associated with investigative journalism.

Crucially, this task can only succeed if there has first been the international cooperation to put in place the infrastructure that will permit the diagnosis to be made. This includes establishing appropriate systems of surveillance and data gathering that make visible the existence of the many millions of the global population whose entry to and departure from this world is unrecorded and thus, essentially, invisible. ${ }^{8}$ It also entails developing teams to undertake the analysis in those parts of the world where the populations are most vulnerable yet where the research capacity is often weakest. ${ }^{9}$ The second task is to develop an effective response to these global threats; this too requires widespread international cooperation.

This glossary seeks to provide a basic introduction to this complex global territory, looking at some of the issues requiring a global response and the means by which the public health community can respond to them. It is important to note that, given the enormous scope of the subject, it cannot hope to be comprehensive but instead reflects the issues felt to be important by the authors and aims to provide some pointers to ideas and resources that might otherwise be overlooked by public health professionals. The glossary is divided into two parts. The first, published here, examines some of the concepts and issues that are relevant to a consideration of international cooperation and health; the second, to be published in a subsequent issue of the journal, will examine the responses to this changing environment.

It complements an earlier glossary in this journal, by Bettcher and Lee, ${ }^{10}$ which examines globalisation and public health, describing key concepts such as global civil society, and global governance. They dealt with the shift towards global systems of governance (undertaken in the health sector by WHO and others) as a result of the decline in each country's capacity to set policy. In contrast, we focus on the ways in which those people making up the international public health community can work 
collaboratively, highlighting where possible how the trends of globalisation can be harnessed for public health benefit. Many of our examples are drawn from tobacco control, reflecting the attention given by the public health community to this issue. However, the issues raised are applicable more widely and, just as companies marketing weapons or junk food or engaged in activities that damage the environment are learning from the tactics used by the tobacco industry, it is also possible from those engaged in promoting health to learn from this comparatively well researched field.

\section{BIOPIRACY}

Biopiracy, or the patenting of biological materials including plants, animals, and even elements of humans, is becoming a key issue of contention between multinational companies and health and other campaigners. The health implications are complex and multifaceted. They include the acquisition of monopolies on products used for diagnosis and treatment (such as the patenting of the BRCA gene that causes some breast cancers), ${ }^{11}$ the acquisition of rights over crops that have been developed by generations of indigenous farmers (such as the attempts by large corporations to patent basmati rice and turmeric), ${ }^{12}$ the indirect effects of the entry of biotechnology companies into agricultural production in developing countries, commonly leading to consolidation of power in the hands of a few and damaging the interests of small producers, and the ecological implications that stem from both the more intensive farming that often accompanies patented products and the loss of biodiversity. There are, however, increasing examples of global alliances that are confronting this threat. One of the leading critics of the multinational companies is Vandana Shiva, whose Research Foundation for Science, Technology and Ecology (RFSTE), ${ }^{13}$ has successfully taken legal action against companies involved in biopiracy.

\section{CITIZENSHIP}

While in theory, globalisation might be expected to entail the lowering of barriers to all types of movement, in practice the rich world has sought to maintain, and frequently to raise, the barriers to free movement of people from the poor world. The imbalance between free movement of capital and services, with restricted movement of people, brings many benefits for multinational companies who can exploit lower wages and poorer employee protection in poor countries. The companies can repatriate profits, often paying few if any taxes, while the workers are unable to move to the rich company to take advantage of its better conditions. However, this can only work as long as governments in industrialised countries maintain strict limits on the award of citizenship.

Of course, increasing numbers of people do move from poor to rich countries, but their inability to gain citizenship can prove a barrier to obtaining essential services, including health care.

In an age of increasing cross border migration, this can prove counterproductive. Firstly, infectious diseases travel as easily as migrant populations so that denying services to recent arrivals places the indigenous population at risk. Secondly, the conditions under which migrant populations live are often conducive to poor health (crowding, lack of ventilation, lack of sanitation), in effect making this group the one most in need of proper health care. Thirdly, although many countries deny non-citizens preventive services, they are bound to provide emergency services, so that they seek care only when the situation has become critical. This proves considerably more expensive for state health systems.

\section{DISINFORMATION}

Just as information underpins international cooperation to promote health, disinformation has often played a part in obstructing effective action. In the past decade the ancient art of propaganda has been refined extensively by an increasingly powerful public relations industry. Most often, these activities are undertaken using third parties, or "front organisations". Some are created by corporations and agencies acting on their behalf; others begin as legitimate pressure groups but are persuaded to shift their focus by offers of funding. Typically these organisations have names that suggest a serious scientific intent, such as the Centre for Indoor Air Research, created by the tobacco industry, ${ }^{14}$ or suggest grassroots activism, such as the Keep America Beautiful campaign, whose refusal to campaign against the major source of litter, discarded tobacco packaging and butts, could only be explained when it was discovered that it was receiving tobacco industry funding. ${ }^{15}$ Tactics include funding questionable research designed to provide the results they want, producing authoritative sounding, but highly biased reports, and media placement of stories favouring their point of view. Often what they publish is technically true, but is only a very small and highly partial part of the truth. Many of these organisations have explicitly set out to create the view that "scientists cannot make up their minds" and that evidence suggesting that their product might have harmful effects is flawed. The web site of PR Watch is a key source of information on the tactics used by these groups. ${ }^{16}$

\section{FENCES AND WINDOWS}

A term coined by the Canadian journalist Naomi Klein, this refers to the way in which many things that were once public are now being surrounded by fences and privatised so that they can be exploited for profit. Examples include water and education in many developing countries, but also the growth in the concept of intellectual property, coupled with technical advances in, for example, genomics, that allows large corporations to expropriate ownership of crops that have been developed by indigenous peoples over centuries. Most literally, they include the fences erected around free trade zones in developing countries in which multinational corporations can operate free from taxes and unconstrained by labour protection laws. Windows relate to the failure of fences, however high, to keep out the dispossessed. Windows are opened in fences in many ways, for example through exposure of the activities of those building them via web sites, consumer boycotts of branded goods, and in some cases, literally tearing the fences down, as when peasant farmers reclaim their traditional lands.

\section{GLOBAL INFORMATION MANAGEMENT}

The use of communication technologies, and the internet in particular, to exchange information, expertise, and ideas rapidly across national borders and simultaneously to link policy makers, academics, and activists is key to attempts by the public health community to work collaboratively. For example, GLOBALink, ${ }^{17}$ an International Union Against Cancer programme formed in 1993, is a key resource for linking tobacco control researchers and advocates internationally, providing them with the opportunity to network, exchange ideas, share and disseminate information. With a worldwide membership of over 4000 tobacco control professionals, GLOBALink has become a recognised catalyst for dialogue and collective action, facilitating the coordination of global campaigns and petitions.

The internet is also an invaluable means of providing access to continuing medical education and lifelong learning far from well funded centres of excellence. ${ }^{18}$ 
Improvements in communication and information technologies have enabled international responses to catastrophic events that threaten health to be organised more rapidly and facilitated the coordination of emergency situations, for instance in the Maharashtra Emergency Earthquake Rehabilitation Project in India. ${ }^{19}$ Imaginative exploitation of geographical information systems can help in the investigation and control of infectious disease outbreaks that cross borders (see also surveillance networks) and the forecasting of epidemics that follow El Niño Southern Oscillation events. ${ }^{5} 18$

\section{GLOBAL PUBLIC GOODS FOR HEALTH}

Public goods are characterised by two features. They are nonexcludable (once provided, their use cannot be restricted to particular people) and they are non-rival in consumption (one person's consumption does not leave less for another). ${ }^{20}$ A classic example is street lighting. Global public goods are those that confer benefits on a global scale. The problem with public goods is that the inability to make a profit from them means that, in a free market, there is no incentive for anyone to produce them. As a consequence, within a country they are typically produced, or paid for, by government. This is clearly not possible on a global scale. Globally, there have been two responses. The first, by many large corporations, is to seek to convert public goods into private goods (see "Fences and windows"). The second is to stimulate debate on how global public goods for health can be produced through concerted global action, typically through international agencies. This debate has extended the strict definition of public goods given above to include all goods for which it makes sense for countries collectively to produce for universal consumption and where it would not make sense to exclude anyone from consuming them. ${ }^{21}$ Examples include the generation of knowledge or the creation of regulatory regimes. A related concept is the access good, which is something that is required to make use of a public good, such as a television set to receive free to view television programmes. Increasingly, effective health systems are viewed as an access good, enabling people to benefit from knowledge.

\section{NO LOGO}

Another term coined by Naomi Klein, it has been adopted by many in the worldwide struggle against the harmful activities of global corporations, ${ }^{22}$ many of which have profound implications for health. Klein contrasts the use of logos, or brands, to convey a positive image of these corporations, emphasising corporate social responsibility, with the reality of their exploitation of workers, in particular those working in sweatshops in developing countries and their disregard for the environment.

\section{PARTICIPATIVE DEMOCRACY}

Although about two thirds of the countries in the world are officially democratic, ${ }^{23}$ the extent to which civil society participates in decision making varies greatly. Its involvement has often been especially limited in the health sector, with health professionals often giving it little emphasis. The HIV/AIDS pandemic and the demands to be heard by those living with this disease has begun to change this paradigm, showing the effectiveness of including affected communities and users of services in decisions involving their health and wellbeing. Such participation helps assure that programmes are designed and implemented mindful of the needs of those who will use them.

\section{PROJECT FOR THE NEW AMERICAN CENTURY}

In June 1997 a neoconservative policy group, the Project for the New American Century, produced a statement of principles that they argued should underpin American foreign and defence policy. Signatories to this statement of principles included Dick Cheney, Donald Rumsfeld, Paul Wolfowitz, and Jeb Bush. It emphasises the need for America to assume a global leadership role, underpinned by a significant increase in defence expenditure, a strengthening of ties to America's allies coupled with a challenge to regimes hostile to American interests, and an acceptance of "America's unique role in preserving and extending an international order friendly to our security, our prosperity, and our principles." Most of the signatories have subsequently been given senior positions in the administration of President George W Bush and the statement is widely seen as an expression of what has become the Bush doctrine. This doctrine views international relations as being based on military and economic power rather than on international law (see also International Law in Bettcher and $\mathrm{Lee}^{10}$ ). As a consequence, as the largest economy and the greatest military power, the USA should impose its values on the rest of the world, values that are viewed as self evidently superior to others because of the USA's apparent economic success. This has been the basis for the American government's opposition to many international agreements and policies designed to promote health, such as the Kyoto Protocol on greenhouse gases, the Landmine Treaty, and the World Health Organisation's Global strategy on diet, physical activity $^{24}$ and health and Framework Convention on Tobacco Control. ${ }^{25}$ It also provides a backdrop for the growing evidence of political interference in science under the Bush administration. $^{26}$

\section{"WHITE COATS"}

An important element of the tobacco industry's strategy against action on smoking has been to recruit ostensibly independent scientists who will dispute the evidence on the health effects of smoking, will write articles to this effect in the popular press, and will appear as expert witnesses in court cases. The original idea came from a senior executive in R J Reynolds who, in 1974, devised a scoring system for scientists working on tobacco to categorise the extent to which they were supportive of the industry's position. However, it was not until the late 1980s that the industry embraced it enthusiastically, when a senior executive from Philip Morris presented a strategy to the major tobacco companies proposing that such scientists (whom they termed "Whitecoats") be recruited actively, primarily as a means of counteracting the growing evidence linking second hand smoke to a range of diseases. This activity was largely undertaken through front organisations whose links with the tobacco industry were concealed, but under the direction of law firms acting on behalf of the tobacco industry, in particular Covington Burling and Shook, Hardy and Bacon. While some of the scientists may have been unaware of the origins of the extensive funding they received, there is growing evidence that others were actively involved in promoting the interests of the tobacco industry.

\section{ACKNOWLEDGEMENTS}

We are grateful to Allyson Pollock, Robert Beaglehole, Ronald Labonte, Kelley Lee, and an anonymous reviewer for comments on earlier drafts.

\section{Authors' affiliations}

M McKee, A B Gilmore, European Centre on Health of Societies in Transition, London School of Hygiene and Tropical Medicine, London, UK

N Schwalbe, Open Society Institute, New York, USA

Funding: none. 
Competing interests: MM is a member of the Open Society Institute's (OSI) public health sub-board and NS is the Director of the Public Health Program at OSI. OSI is committed to building open societies through collaboration between non-governmental organisations, governments, and international organisations. AG is funded by the US National Institute of Health to work on tobacco industry documents. The views expressed cannot be taken as representing any of the organisations they are associated with.

\section{REFERENCES}

1 McKee M, Garner P, Stott R, eds. International co-operation and health Oxford: Oxford University Press, 2001.

2 Campbell C. Blood diamonds: tracing the deadly path of the world's most precious stones. Boulder, CO: Westview Press, 2002

3 Annan K. Report of the panel of experts on the illegal exploitation of natural resources and other forms of wealth of the Democratic Republic of the Congo. New York: United Nations, 2001.

4 Collier P. Breaking the conflict trap: civil war and development policy. Washington DC: World Bank and Oxford University Press, 2003.

5 Haines A, Patz JA. Health effects of climate change. JAMA 2004;291:99-103.

6 McKee M. Epidemiology in the 21 st century: the challenges ahead. Eur J Public Health 2001;11:241-2.

7 McKee M. Competing interests: the importance of transparency. Eur J Public Health 2003;13:193-4.

8 Sibai AM. Mortality certification and cause-of-death reporting in developing countries. Bull WHO 2004;82:83.

9 Beaglehole R, Bonita R, Horton R, et al. Public health in the new era: improving health through collective action. Lancet 2004;363:2084-6.

10 Bettcher D, Lee K. Globalisation and public health. J Epidemiol Community Health 2002;56:8-17.
11 Williams-Jones B. History of a gene patent: tracing the development and application of commercial BRCA testing. Health Law J 2002;10:123-46. 12 Khor M. A worldwide fight against biopiracy and patents on life. http:// www.twnside.org.sg/title/pat-ch.htm.

13 Research Foundation for Science, Technology and Ecology. http:// www.vshiva.net/ (accessed 1 Aug 2004).

14 Barnes DE, Bero LA. Industry-funded research and conflict of interest: an analysis of research sponsored by the tobacco industry through the Center for Indoor Air Research. J Health Polit Policy Law 1996;21:515-42.

15 Lamb W. Keep America beautiful: grassroots non-profit or tobacco front group? PR Watch Archives 2001: 8. http://www.prwatch.org/prwissues/ 2001Q3/kab.html (accessed 1 Aug 2004).

16 PR Watch. http://www.prwatch.org (accessed 1 Aug 2004).

17 Globalink. http://www.globalink.org/ (accessed 1 Aug 2004).

18 Saker L, Cannito B, Lee K, et al. Globalisation and infectious diseases: a review of the linkages. Geneva: WHO Special Programme on Tropical Diseases Research, 2004.

19 Maharashtra Emergency Earthquake Rehabilitation. http:// www.maharashtra.gov.in/index/statelnitiatives/meer.php (accessed 1 Aug 2004).

20 Kaul I, Grunberg I, Stern MA. Global public goods: international co-operation in the 21 st century. New York: Oxford University Press, 1999.

21 Smith R, Beaglehole R, Woodward D, et al. Global public goods for health. Oxford: Oxford University Press, 2003.

22 No Logo. http://www.nologo.org/ (accessed 1 Aug 2004)

23 Karatnycky A. Freedom in the world: the annual survey of political rights and civil liberties 2004. New York: Freedom House, 2004.

24 Dyer O. United States wins more time to lobby against WHO diet plan. BMJ 2004;328:245.

25 Gilmore A, Collin J. A wake up call for global tobacco control: will leading nations thwart the world's first health treaty? BMJ 2002;325:846-7.

26 McKee M, Novotny TE. Political interference in American science: why Europe should be concerned about the actions of the Bush administration. Eur J Public Health 2003;13:289-91. 